\title{
Preparation and purification of lymphocytes from the epithelium and lamina propria of murine small intestine
}

\author{
M D J DAVIES* AND D M V PARROTT \\ From the Department of Bacteriology and Immunology, Western Infirmary, Glasgow
}

SUMMARY Existing methods for the production of lymphocytes from the small intestine have proved unsatisfactory when applied to the mouse. We report here a new method for the production of highly pure suspensions of lymphoid cells from the epithelial layer and lamina propria of mouse small intestine. The production and purification methods are described in detail. At least ten million lymphocytes are obtainable from each small intestine from either the epithelium or lamina propria and the cell suspensions are shown to be little contaminated by non-lymphoid cells. Preliminary analysis of the two cell types indicates that they belong either to two separate populations or to one population in very different stages of differentiation. The use of purified lymphoid cells from the epithelium and lamina propria of the small intestine may enable examination of the generation of cytotoxicity towards gut epithelial cells; this may be important in the development of inflammatory bowel diseases.

With increasing interest being shown in the immunology of the gut, it has become necessary to produce pure populations of lymphoid cells from the intestine to examine their immune effector function. Potentially the small intestine can yield lymphocytes both from the epithelial layer, the so-called intraepithelial lymphocytes, and from the lamina propria. So far, the majority of studies have been carried out on human small or large bowel tissue where two methods of extraction have been tried: mechanical ${ }^{1-3}$ and enzymic. ${ }^{3-5}$ Mechanical and enzymic extraction techniques have also been tried with varying success on experimental animal intestinal tissue. $^{6-8}$ In the vast majority of these studies, 'mucosal' lymphocytes have been extracted with little regard to their origin from the epithelial layer or lamina propria. In view of the observation $^{8 \mathrm{a}}$ that cytotoxic $\mathrm{T}$ cells in the epithelial layer appear to have a different cytotoxic potential from those in the lamina propria, it is necessary to examine separately lymphoid cells from the two layers when assessing effector function.

We report here an efficient, economical, and reproducible technique for producing lymphoid

*Address for correspondence: Dr M D J Davies, Department of Bacteriology and Immunology, Western Infirmary, Glasgow G11 6NT Scotland.

Received for publication 18 December 1980. cells from mouse small intestine epithelium and lamina propria. The cells are obtainable in very high purity and viability and preliminary observations on some of the properties of the isolated cells show that the two populations are different.

\section{Methods}

A N I M A L S

C57B1 10 ScSn, DBA/2, CBA/Ca, and Balb/c mice were supplied and bred from department stocks. Age- and sex-matched mice were used within any one experiment.

M E D I A

RPMI $1640 \times 10$ concentrate (Gibco Biocult) was brought to isotonicity $(308 \mathrm{mOsmol} / \mathrm{kg})$ by dilution with $10 \mathrm{mM}$ HEPES, $25 \mathrm{mM}$ sodium bicarbonate buffer, and corrected to $\mathrm{pH} 7 \cdot 2$ with $5 \mathrm{~N}$ sodium hydroxide. This medum was routinely supplemented with $5 \%$ heat-inactivated newborn calf serum (NCS; Gibco), $2 \mathrm{mM}$ L-glutamine, $100 \mathrm{units} / \mathrm{ml}$ penicillin and $100 \mu \mathrm{g}$ streptomycin (Gibco). The addition of $30 \mu \mathrm{g} / \mathrm{ml}$ gentamicin (Sigma) is recommended during the extraction procedure if the cells are to be cultured.

Calcium and magnesium ion free Hanks' bal. anced salt solution (CMF) (from 10) was made up as a $\times 10$ concentrate and diluted to isoton- 
icity using the HEPES-bicarbonate buffer as above. $\mathrm{pH}$ was corrected to $\mathbf{7 \cdot 2}$.

\section{H E M I C A L S}

Chemicals and enzymes used in these experiments were supplied from the following sources: ethylenediaminetetraacetic acid (EDTA BDH Analar); collagenase types C-2139 and C-6885, bovine serum albumin fraction V (Sigma); Worthington collagenase type CLSPA (Millipore UK); Percoll, Ficoll 400 (Pharmacia); Triosil 440 (Nyegaard; Vestric); all stains (Gurr; GD Searle).

\section{A N T I - T C E L L A N T IS E R U M}

Rabbit anti-mouse $T$ cell serum was prepared by $\mathrm{Mr}$ John Shields of this department by two intravenous injections of $\mathrm{Balb} / \mathrm{c}$ and CBA thymocytes followed by a single subcutaneous injection of $1 \mathrm{ml}$ of a CBA-Balb/c brain homogenate mixture in complete Freund's adjuvant. The rabbit was bled out two months later, the serum extracted, and heat inactivated for 45 minutes at $56^{\circ} \mathrm{C}$. The serum was absorbed twice against homogenised mouse liver and once against mouse bone marrow cells. This serum, at a $1: 40$ dilution in a cytotoxic assay using $1: 5$ diluted guinea-pig serum as a source of complement, killed $95 \%$ of thymocytes, $2 \%$ of bone marrow cells, and $59 \%$ of peripheral lymph node lymphocytes.

\section{EN U M ERATI ON OF T CELLS}

The number of $T$ cells was enumerated by treating cell suspensions with the anti-mouse $T$ cell serum, incubating for 45 minutes at $37^{\circ} \mathrm{C}$, and then adding guinea-pig serum as a source of complement to a final dilution of $1: 10$. After incubation for 45 minutes at $37^{\circ} \mathrm{C}$, the number of viable cells in the suspension was assessed.

\section{S T A I N I G METHODS}

Staining was performed on cell suspensions cytocentrifuged on to slides. Methyl-green pyronin and Leishman staining followed standard methods. For 18 hour Giemsa staining, slides were fixed in methanol and stained overnight in a $1: 20$ dilution of stock Giemsa in pH6.5 Sörensen's phosphate buffer. Slides were differentiated in $0.25 \%$ colophonium resin in methylated spirit and then mounted as usual. Astra blue staining: slides were fixed in Carnoy's fluid, dried and rehydrated then stained for 30 minutes in $0.1 \%$ astra blue in $0.7 \mathrm{~N}$ hydrochloric acid, $\mathrm{pH} 0.3$. After washing in $0.7 \mathrm{~N} \mathrm{HCl}$, slides were lightly counterstained in safranin, washed, dehydrated, and mounted. Acid $\alpha$-naphthyl acetate esterase (ANAE) followed the method of Ranki, Tötterman, and Häyry ${ }^{10}$ with counterstaining in $0.1 \%$ toluidine blue.

ROSETTING METHODS

Enumeration of complement-receptor bearing cells $\left(E A C^{\prime}\right)$ by the rosette method was performed using standard techniques with a suitable difution of rabbit anti-sheep red cell haemolysin (Flow Labs.) and a 1:10 dilution of autologous mouse serum as a source of complement. Rosettes were clarified by lightly staining with $0 \cdot 1 \%$ methylene blue.

MEASUREMENT OF CELL V I A B I L I T Y Cell viability was assessed by the ability of viable cells to exclude $0.2 \%$ eosin in RPMI.

\section{G L A S S W A R E}

All glassware was thoroughly washed with detergent, treated with $1 \%$ silicone fluid (MS 1107) in ethyl acetate for 20 seconds, rinsed with distilled water, and baked for one hour at $160^{\circ} \mathrm{C}$.

PREPARATION OF CELL S USPENSION S 1. Mesenteric lymph nodes

Nodes were removed and disrupted either by forcing through a fine stainless steel screen or by teasing apart with a scalpel blade. After filtration through a small column of sterile glass wool (May \& Baker) in a $10 \mathrm{ml}$ syringe, cell suspensions were washed twice in medium before use.

\section{Lamina propria lymphocytes (see Figure for} flow chart of method)

Stagle 1 Small intestines were removed from animals and handled in batches of three. The guts were thoroughly washed through with cold CMF using a $50 \mathrm{ml}$ syringe fitted with a short plastic cannula. This removed all food remains and much mucus.

Thorough washing of the gut is essential, not only to remove food but also to clarify Peyer's patches for their subsequent removal. Although a flush through of $10 \mathrm{ml}$ of CMF per gut is sufficient to delineate Peyer's patches, the use of $40-50 \mathrm{ml}$ per gut results in less debris being encountered in later stages. Mucus has not been found to be of any problem in the mouse and, although various mucolytic agents such as dithioerythritol have been added during the initial incubations, they make no difference to the final yield. 


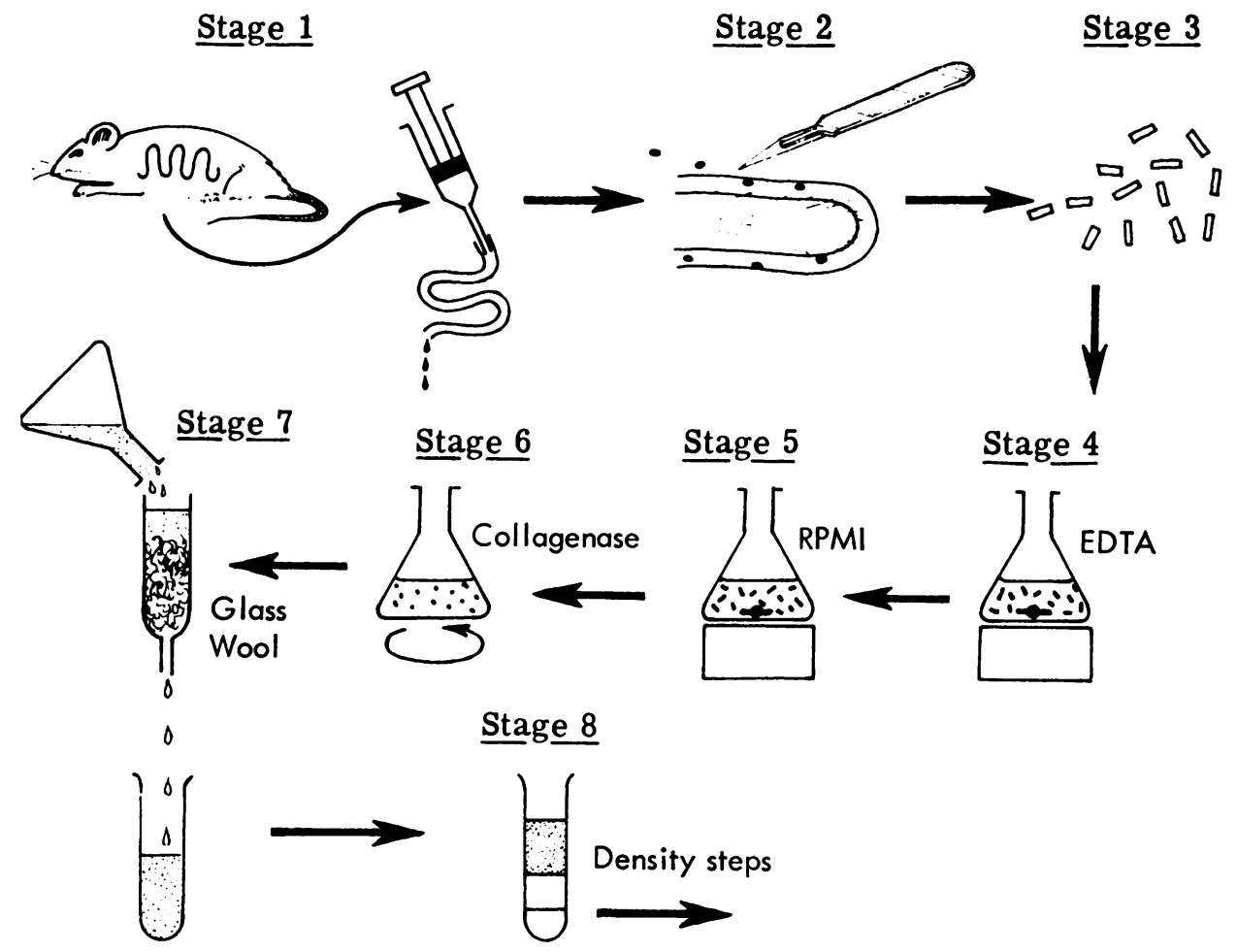

Fig. Flow diagram of preparation of lamina propria lymphocytes.

Stage 2 The cleaned small intestines were then placed on CMF-moistened paper towels and all Peyer's patches, blood vessels, fat, and mesentery were completely removed.

Removal of all macroscopic Peyer's patches is essential, so that they do not contaminate the final preparations. Removal of all adherent fat from the intestine improves the final yield and removal of blood vessels decreases the number of red blood cells which need to be removed in the purification stages.

Stage 3 The intestines were then opened longitudinally and cut laterally into small pieces $(0 \cdot 5-1 \mathrm{~cm})$. These pieces were well washed in CMF in a $50 \mathrm{ml}$ flask by aspiration of the supernatant and addition of clean CMF.

Separation of the gut into small pieces (about $0.5 \mathrm{~cm}$ long) is advisable for maximal cell yield and, again, good washing of the pieces in CMF is advantageous.

Stage 4 After addition of $25 \mathrm{ml} 5 \mathrm{mM}$ EDTA in CMF, the guts were incubated at room temperature with a magnetic stirrer at $250 \mathrm{rpm}$ to remove the epithelium. When the supernatant fluid became sufficiently clouded with cells, it was removed and fresh EDTA/CMF added (usually every 15 minutes). After about 90 minutes, no more cells were seen in the supernatant indicating that all the epithelium had been removed. This was confirmed by histological examination of the remaining fragments.

EDTA/CMF at $25^{\circ} \mathrm{C}$ has been found to be optimal. Although it was suggested that $90 \mathrm{~min}$ utes was sufficient to remove all the epithelium, it is necessary to carry on the EDTA treatment until the supernatant is clear of cells. This can sometimes take as long as 120 minutes. The gut pieces can be left in EDTA/CMF for several hours longer without obvious detriment as judged by histological examination of the remaining pieces. However, as no tests on the subsequent functional capacity of cells have been carried out after long incubations in EDTA, it would seem advisable to process the samples as quickly as possible.

Stage 5 The pieces were then washed with CMF and incubated for 20 minutes with stirring 
in $25 \mathrm{ml} \mathrm{RPMI/NCS} \mathrm{to} \mathrm{inactivate} \mathrm{any} \mathrm{remain-}$ ing EDTA.

Stage 6 The remaining fragments were then transferred to flasks containing $15 \mathrm{ml}$ RPMI/ NCS containing collagenase. The amount of collagenase used varied for each type; types C-2139 and C-6885 were used at between 10 units and 90 units $/ \mathrm{ml}$, and CLSPA at 10 units $/ \mathrm{ml}$. The flasks and contents were then incubated at $37^{\circ} \mathrm{C}$ in an orbital incubator (Gallenkamp type IH 460 ) for 90 minutes at 180 cycles/minute. For the last 15 minutes of this incubation, the flasks were transferred again to the magnetic stirrer to facilitate final disruption of the gut pieces. Use of the orbital incubator alone results in poor yields; using the stirrer alone results in many of the freed cells being killed, hence decreasing the yield of viable cells after purification. As an alternative to the magnetic stirrer, the gut pieces can be put into a universal container and pumped slowly up and down through a $5 \mathrm{ml}$ syringe to effect total disruption. The choice of collagenase type depends on what the cells are subsequently required for. Type C-2139 has been found to be the most efficient at 90 $\mathrm{U} / \mathrm{ml}$ for a maximum yield, although $10 \mathrm{U} / \mathrm{ml}$ and the use of syringe disruption rather than magnetic stirrer produces adequate yields. This type of collagenase does have some trypsin activity, which may affect the expression of surface components or cellular function. However, it does not affect cytotoxic $\mathrm{T}$ cell activity as already reported. ${ }^{11}$ Type C-6885 used at $10 \mathrm{U} /$ $\mathrm{ml}$ produces lower yields of cells but has no detectable effects on the cells which could be attributed to trypsin. Type CLSPA at $10 \mathrm{U} / \mathrm{ml}$ is the least efficient in terms of yield but, as this enzyme is free from tryptic and protease activity, i's use in some experiments might be required. The use of type CLSPA at $90 \mathrm{U} / \mathrm{ml}$ is not necessary, nor, we consider, financially warranted.

Stage 7 The resultant 'soup' was then filtered through a glass wool column as previously described and washed twice with RPMI/NCS. This provided a single cell suspension still significantly contaminated with dead cells and debris which needed further purification as described below (stage 8).

\section{Intraepithelial lymphocytes}

The method used was adapted from a technique developed by Dr. Allan Mowat (personal communication, BSc project, 1975). The small intestines were prepared initially in the same way as described for lamina propria cells. After stage 3, the small gut pieces were put into a $50 \mathrm{ml}$ siliconised flask with $20 \mathrm{ml}$ RPMI $/ 2 \%$ NCS (more serum causes foaming) and incubated for 30 minutes at $37^{\circ} \mathrm{C}$ in a shaking water bath. The gut pieces were then transferred to a universal container and shaken vigorously for 15 seconds. The supernatant fluid was removed and replaced and the shaking process repeated. When the supernatant fluid was clear, the gut pieces were incubated in a conical flask for another 30 minutes at $37^{\circ} \mathrm{C}$ in the shaking water bath and the original procedure repeated. All the supernatants were then pooled, centrifuged, resuspended, and filtered through glass wool and then washed several times. The resulting cell suspension contained lymphocytes, epithelial cells, and debris and required further purification as described in stage 8 below. Comments for stages 1 to 3 above apply also in this case. It should be stressed that adequate washing of gut pieces is necessary before incubation at $37^{\circ} \mathrm{C}$ to reduce the amount of debris. At the shaking stage, removal of the supernatant fluid and replacement with fresh medium should be repeated until the supernatant is relatively cellfree as this improves the cell yield.

Stage 8 Furification of intraepithelial and lamina propria cell suspensions: three different methods were tried:

1. Ficoll-Triosil This method was repeated as described by Davidson and Parish ${ }^{12}$ and usually provided a reasonable purification of viable mono-nuclear cells, although the yield of cells was often low. However, if the original preparation was grossly contaminated, then purification was usually incomplete.

2. Bovine serum albumin (BSA-6) Discontinuous steps of $10 \%, 28 \%$, and $35 \%$ w/v BSA were used. Apart from the usual handling problems of high concentrations of BSA and the fact that the crude material had to be purified before use, pure mononuclear cell suspensions were found at the $28 \% / 35 \%$ BSA interface. The technique suffered the same problems as with Ficoll-Triosil, coupled with those due to the high viscosity of BSA solutions.

3. Percoll Stock working solutions of isotonic Percoll were made up according to Ulmer and Flad. ${ }^{13}$ Solutions of density $1.055 \mathrm{~g} / \mathrm{ml}$ and $1.085 \mathrm{~g} / \mathrm{ml}$ were made up from the $1 \cdot 120 \mathrm{~g} / \mathrm{ml}$ stock by dilution with RPMI only. Densities were checked by refractometry at $20^{\circ} \mathrm{C}$ with a standard curve of refractive index (RI) against density. Density steps were made up at $4^{\circ} \mathrm{C}$ in $10 \times 1.5 \mathrm{~cm}$ 
siliconised glass tubes; $1 \mathrm{ml} 1.085 \mathrm{~g} / \mathrm{ml}$ Percoll $(\mathrm{RI}=1.3464)$ was overlaid with $2 \mathrm{ml} 1.055 \mathrm{~g} / \mathrm{ml}$ Percoll (RI 1.3420) then $3 \mathrm{ml} \mathrm{RPMI/NCS}$. Alternatively, $2 \mathrm{ml} 1.055 \mathrm{~g} / \mathrm{ml}$ and $4 \mathrm{ml} 1.055 \mathrm{~g} / \mathrm{ml}$ Percoll in a siliconised universal container were used. The cell suspension was resuspended in either the $1.055 \mathrm{~g} / \mathrm{ml}$ layer or the overlaying RPMI/NCS. After centrifugation at $600 \mathrm{~g}$ for about 20 minutes at $4^{\circ} \mathrm{C}$ (MSE Mistral 2L, swingout head), highly viable mononuclear cells could be recovered from the $1 \cdot 055 / 1.085 \mathrm{~g} / \mathrm{ml}$ interface. Dead cells, debris, and epithelial cells were found at the upper interface and red blood cells in the pellet. The yield of purified cells depends on the number of cells loaded on to the Percoll steps and the contamination of the suspension by debris and epithelial cells. If this is the case, it is better initially to resuspend the cells in $1.055 \mathrm{~g} / \mathrm{ml}$ Percoll instead of in RPMI/NCS. If care is taken throughout the preparation, the yield of viable cells from the second Percoll interface can be as high as $90 \%$ of the number of viable cells put on at the beginning. In the case of high contamination of the original suspension, the resultant cell yield at the second interface is reduced, although the purity does remain high. The viabilty of cells taken from the second interface always exceeds $90 \%$.

The use of Percoll to purify the cell suspensions is found to be the simplest and most economic method and results in the best yields.

\section{Results}

Methods for producing purified lymphoid cells from the epithelial layer and lamina propria of the small intestine of the mouse have been described. Although the two techniques are described separately, the two cell suspensions can be produced from the same group of intestines. If, after isolating the intraepithelial lymphocytes (IEL), suspensions of lamina propria lymphocytes (LPL) are required, the LPL separation technique can be resumed at stage 4 , the time for the EDTA incubation being reduced by half.
T I M E F O R P REPARATION OF CELLS Preparation time for intraepithelial and lamina propria lymphocytes from the time of killing the animals to the end of final purification is three to four hours and four to five hours respectively.

VAR IATION OF CELL YIELD W ITH

MOUSE STRAIN A N D A GE

Lamina propria cells have been prepared from C57B1, DBA/2, Balb/c, and CBA/Ca mice. There does not appear to be any difference in the cell yield from any of these strains. Within C57Bl mice, cell preparations have been made from animals varying in age between 6 and 24 weeks. Although all the cell yields were within the range quoted below, it has been found that mice of 812 weeks in age represent a compromise of gut size and lack of fat deposits both of which affect the final cell yield. The average cell yield was $9 \times 10^{6}$ to $1.8 \times 10^{7}$ cells per mouse for intraepithelial lymphocytes and $5 \times 10^{6}$ to $1.6 \times 10^{7}$ cells per mouse for lamina propria lymphocytes.

\section{CHARACTERISATION OF PURIFIED}

C E L L S

\section{Composition of cell populations}

On the basis of Leishman staining, IEL and LPL suspensions have been characterised as shown in Table 1. After purification on Percoll, both cell suspensions contain at least $90 \%$ lymphocytes. In the IEL, the contaminating cells are mainly epithelial while the LPL are slightly contaminated with macrophages and eosinophils. The two lymphocyte populations from the gut do however vary in size. Table 2 shows the size classification of IEL, LPL, and mesenteric lymph node lympho-

Table 2 Size characteristics of cell populations

\begin{tabular}{llccc}
\hline $\begin{array}{l}\text { Mouse and } \\
\text { cell type }\end{array}$ & \multicolumn{3}{l}{ Lymphocyte size $(\%$ of total $)$} & \multicolumn{2}{l}{$\begin{array}{l}\text { No. of cells } \\
\text { counted }\end{array}$} \\
\cline { 2 - 4 } & Small & Medium & Large & count \\
\hline C57Bl MLN & $85 \cdot 4$ & $9 \cdot 2$ & $5 \cdot 4$ & 500 \\
C57Bl IEL & $86 \cdot 5$ & $8 \cdot 0$ & $5 \cdot 5$ & 2561 \\
C57Bl LPL & $49 \cdot 7$ & $39 \cdot 0$ & $11 \cdot 3$ & 600 \\
\hline
\end{tabular}

Table 1 Leishman staining characteristics of lymphocytes isolated from small intestine

\begin{tabular}{lllll}
\hline $\begin{array}{l}\text { Mouse and } \\
\text { cell type }\end{array}$ & \multicolumn{2}{c}{$\%$ of total counted* } & \multicolumn{2}{c}{$\begin{array}{c}\text { Total no. of } \\
\text { cells counted }\end{array}$} \\
\cline { 2 - 5 } C57B1 IEL & Macrophages & Granulocytes & Others \\
C57B1 LPL & $94 \cdot 2 \pm 1 \cdot 8$ & $1 \cdot 1 \pm 0 \cdot 5$ & $\dagger$ & $4 \cdot 7 \pm 1 \cdot 7$ \\
\hline
\end{tabular}

Others: epithelial cells, mast cells, free nuclei.

*Mean $\pm S D$ of three separate experiments.

†Less than 1 cell in 500 . 
cytes (MLN) based on their staining characteristics. MLN and IEL are very similar in size, while LPL suspensions contain a larger proportion of medium and large lymphocytes.

\section{RNA synthesis of cell populations}

Table 3 shows the number of RNA synthesising cells, assessed by pyronin staining, found in MLN, IEL, and LPL suspensions. Nearly half the lymphocytes isolated from the lamina propria are pyronin positive with only $10 \%$ in MLN. IEL contain intermediate numbers of pyronin positive cells to MLN and LPL.

\section{Surface markers on cell populations}

Data for Thy 1.2 and complement-receptor bearing cells are shown in Table 4. IEL and LPL both have low numbers of complement-receptor bearing cells compared with MLN. The measurements on LPL were made on cells extracted with collagenase type C-6885 which was not found to alter the levels of receptors found on MLN cells so treated. MLN and IEL contain similar numbers of $\mathrm{T}$ cells exnressing the Thv 1.2 marker. while LPL suspensions have significantly more $\mathrm{T}$ cells.

\section{Granule containing cells}

After staining with Giemsa overnight or with Astra blue, some lymphocytes have been found to contain cytoplasmic granules. These cells have otherwise typical lymnhoid morphology and do not resemble mast cells. IEL suspensions have been found to contain $36 \cdot 2 \pm 4 \cdot 2 \%$ of cells containing such granules. However, no granule containing cells have been found in MLN or LPI.

Table 3 Methyl-green pyronin staining characteristics of cell populations

\begin{tabular}{lll}
\hline $\begin{array}{l}\text { Mouse and } \\
\text { cell type }\end{array}$ & $\begin{array}{l}\text { Pyronin } \\
\text { positive cells }(\%)\end{array}$ & $\begin{array}{l}\text { Total no. of } \\
\text { cells counted }\end{array}$ \\
\hline C57B1 MLN & 10 & 1000 \\
C57B1 IEL & $19 \cdot 7$ & 2000 \\
C57B1 LPL & $42 \cdot 4$ & 4070 \\
\hline
\end{tabular}

Table 4 Surface markers on cell populations

\begin{tabular}{lll}
\hline $\begin{array}{l}\text { Mouse and } \\
\text { cell type }\end{array}$ & $\begin{array}{l}\text { EAC' positive* } \\
(\%)\end{array}$ & $\begin{array}{l}\text { Thy } 1.2 \text { positive* } \\
(\%)\end{array}$ \\
\hline C57Bl MLN & $19 \cdot 1 \pm 5 \cdot 5$ & $60 \cdot 8 \pm 9 \cdot 4$ \\
C57Bl IEL & $2 \cdot 9 \pm 0 \cdot 6$ & $65 \cdot 2 \pm 8 \cdot 1$ \\
C57B1 LPL & $6 \cdot 6 \pm 2 \cdot 1$ & $79 \cdot 9 \pm 6 \cdot 7$ \\
\hline
\end{tabular}

*Mean \pm SD of four to six separate experiments. At least 2000 cell counted in total. suspensions after the examination of at least 10000 cells.

Acid $\alpha$-naphthyl acetate esterase ( $A N A E$ ) staining Punctate staining of cells with ANAE positive material is a marker for resting $T$ cells in the mouse. ${ }^{10}$ We have stained MLN, IEL, and LPL suspensions many times with ANAE and have found the results unreliable. As the number of activated $T$ cells in the guts of normal animals varies, the ANAE staining is probably of little value. However, initial data suggest that MLN, IEL, and LPL all contain around $40 \%$ ANAE positive cells.

\section{Discussion}

Much of our knowledge of the gut mucosal effector system has stemmed from experiments on mesenteric lymph node and Peyer's patch lymphocytes. However, to understand mucosal effector functions clearly, we must examine lymphocytes from within the gut itself. The methods described in this paper provide the means to examine such functions. We have already used such methods to show that cytotoxic $\mathrm{T}$ cell capacities in mouse mesenteric lymph nodes, Peyer's patches, and lamina propria vary markedly. ${ }^{11}$

The majority of lymphocyte preparation techniques from the gut, both in humans and in experimental animals, produce suspensions of 'mucosal lymphocytes' which are clearly a mixture of IEL and LPL. ${ }^{25}$ In view of our observation $^{8 \mathrm{a}}$ that cvtotoxic $\mathrm{T}$ cell activities in IEL and LPL vary, it is necessary that we should examine the two populations separately. We have several reasons for believing that we have isolated two different populations. Firstly, the preparation technique for IEL does not disrupt the lamina propria as assessed by histological examination. Secondly, the EDTA treatment used in the LPL preparation completely removes identifiable epithelium. Thirdly, it appears that lymphocytes containing cytoplasmic granules are a marker for IEL and such cells have never been found in our LPL preparations. Fourthly, the cytotoxic $T$ cell experiments already mentioned lead us to believe that both IEL and LPL represent different populations or a single population at very different stages of differentiation.

The preparation technique for IEL is particularly amenable for the subsequent analysis of effector cell function, as it does not require the 
use of enzymes or dissociation media. We have tried preparing LPL by a mechanical technique to obviate the use of enzymes. After EDTA treatment, the gut pieces were homogenised in a loose-fitting glass homogeniser. However, in agreement with the observations of Bland et al., ${ }^{3}$ we found cell clumping to be a major problem and thus cell yields were low. The addition of indomethacin to the medium was found to decrease clumping but this agent is known to alter many cellular functions including cytotoxic activity ${ }^{14}$ and its use should be avoided.

To our knowledge, there has only been one published study on mouse mucosal lymphocytes, that of Guy-Grand et al. ${ }^{15}$ on IEL. Their preparation technique is less rigorous than ours, which explains the lower yields, and the scant details given of the purification technique do not allow much further comparison. Our experience of the Ficoll-Triosil gradients as used by them have not been favourable and cell suspensions are often grossly contaminated. Their data suggest that there are equal numbers of $T$ cells in the epithelium and lamina propria amounting to $80-90 \%$ of the total number of lymohocytes; our data would suggest that there are slightly fewer $T$ cells in the epithelial layer. We do confirm the data on the number of granulated cells found in the epithelium but not the size profile of IEL. The profile that Guy-Grand et al. give for the size of IEL is similar to that which we have found for LPL, whereas we find that IEL are rather smaller cells. Size classifications done on the hasis of stained cell prenrations. however. are rather subjective and thus it is difficult to compare experiments done hv different workers.

Neither LPL nor IEL contain sionificant numbers of cells bearing recentors for the $\mathrm{C} 3 \mathrm{~h}$ component of complement. This is supnorted by the observation that $\mathrm{C} 3 \mathrm{~b}$ recentor bearing Igpositive B lymnhohlasts from mesenteric lvmph nodes do not home to the gut in sionificant numbers. ${ }^{16}$ The data shown in Table 4 , along with the observation of Guv-Grand et al. that there are very few surface Ig bearing cells in IEL, would suggest that there are some $20 \%$ of cells in IEL without normal surface markers-'null cells'.

The preparation of human gut mucosal lymphocytes has been utilised to measure cell-mediated reactions erpeciallv in natients with bowel disease. The data on the cytotoxic capacity of gut lymphocytes from such patients are very variable ${ }^{317}$ and probably a consequence of the assortment of preparation techniques used. Some of the enzymes used can alter the cytotoxic potential expressed by cells, ${ }^{18}$ while mechanical disruption of mucosal tissue induces the release of prostaglandins which can also alter cytotoxic expression. ${ }^{19}$ Using an animal model of gut lymphocyte preparation, we can examine the effects of different preparation techniques on cell function and explore some of the properties of the cells in a system which is more open to experimentation. In particular, we can now examine the generation of cytotoxicity in LPL and IEL against gut epithelial cells.

It is a pleasure to acknowledge the expert technical assistance of Mrs Sheila MacKenzie. This work was funded by the MRC, grant number G977/623/S.

\section{References}

${ }^{1}$ Clancy R. Isolation and kinetic characteristics of mucosal lymphocytes in Crohn's disease. Gastroenterology 1976; 70:177-80.

${ }^{2}$ Goodacre R, Davidson R, Singal D, Bienenstock J. Morphologic and functional characteristics of human intestinal lymphoid cells isolated by a mechanical technique. Gastroenterology 1979; 76: 300-8.

${ }^{3}$ Bland PW, Richens ER, Britton DC, Lloyd JV. Isolation and purification of human large bowel mucosal lymphoid cells: effect of separation technique on functional characteristics. Gut 1979; 20: 1037-46.

${ }^{4}$ Bull DM, Bookman MA. Isolation and functional characterisation of human intestinal mucosal lympoid cells. J Clin Invest 1977; 59:966-74.

${ }^{5}$ Crofton RW, Cochran C, McClelland DBL. Preparation of lympoid cells from small specimens of human gastro-intestinal mucosa. Gut 1978; 19:898906.

${ }^{6}$ Rudzik O, Bienenstock J. Isolation and characteristics of gut mucosal lymphocytes. Lab Invest 1974; 30:260-6.

${ }^{7}$ Castro GA, Roy SA, Stockstill RD. Trichinella spiralis: peroxidase activity in isolated cells from the rat intestine. Exp Parasitol 1974; 36:307-15.

${ }^{8}$ Arnaud-Battandier F, Bundy BM, O'Neill M, Bienenstock J, Nelson DL. Cytotoxic activities of gut mucosal lymphoid cells in guinea pigs. $J$ Immunol 1978; 121:1059-65.

${ }^{8 \mathrm{a}}$ Davies MDJ, Parrott DMV. Cytotoxic T cells in small intestine epithelial, lamina propria, and lung lymphocytes. Immunology 1981 (in press).

${ }^{9}$ Hanks JH, Wallace RE. Relation of oxygen and temperature in the preservation of tissue by refrigeration. Proc Soc Exp Biol Med 1949; 71: 196-200.

${ }^{10}$ Ranki A, Tötterman TH, Hävry P. Identification of mouse $T$ and $B$ lymphocytes from cytocentrifuged cell smears. Clin Exp Immunol 1976; 26:632-40. 
${ }^{11}$ Davies MDJ, Parrott DMV. The early appearance of specific cytotoxic $T$ cells in murine gut mucosa. Clin Exp Immunol 1980; 42:273-9.

${ }^{12}$ Davidson WF, Parish CR. A procedure for removing red cells and dead cells from lymphoid cell suspensions. J Immunol Methods 1975; 7:291-300.

${ }^{13}$ Ulmer AJ, Flad H-D. Discontinuous density gradient separation of human mononuclear leucocytes using Percoll as gradient medium. J Immunol Methods 1979; 30:1-10.

${ }^{14}$ Droller MJ, Perlmann P, Schneider MU. Enhancement of natural and antibody-dependent lymphocyte cytotoxicity by drugs which inhibit prostaglandin production by tumour target cells. Cell Immunol 1978; 39:154-64.

${ }^{15}$ Guy-Grand D, Griscelli C, Vassalli P. The mouse gut $\mathrm{T}$ lymphocyte, a novel type of $\mathrm{T}$ cell. $J$ Exp Med 1978; 148:1661-77.

${ }^{16} \mathrm{McW}$ illiams M, Phillips-Quagliata JM, Lamm ME. Characteristics of mesenteric lymph node cells homing to gut-associated lymphoid tissue in syngeneic mice. J Immunol 1975; 115:54-8.

${ }^{17}$ Clancy R, Pucci A. Absence of $K$ cells in human gut mucosa. Gut 1978; 19:273-6.

${ }^{15 K e d a r ~ E, ~ O r t i z ~ D e ~ L a n d a z u r i ~ M, ~ F a h e y ~ J L . ~}$ Enzymatic enhancement of cell-mediated cytotoxicity and antibody-dependent cell cytotoxicity. J Immunol 1974; 112:26-36.

${ }^{19}$ Droller MJ, Schneider MU, Perlmann P. A possible role of prostaglandins in the inhibition of natural and antibody-dependent cell-mediated cytotoxicity against tumour cells. Cell Immunol 1978; 39:165-77. 